\title{
ПРОБЛЕМА МУЗЫКАЛЬНО-ИСПОЛНИТЕЛЬСКОГО ОСВОЕНИЯ ЦИКЛА С. ПРОКОФЬЕВА «ДЕТСКАЯ МУЗЫКА» В УЧЕБНО-ОБРАЗОВАТЕЛЬНОМ ПРОЦЕССЕ
}

\section{THE PROBLEM OF MUSICAL AND PERFORMING DEVELOPMENT} OF S. PROKOFIEV'S CYCLE "CHILDREN'S MUSIC" IN THE EDUCATIONAL PROCESS

\section{T. Kezevadze}

Summary: The article is devoted to the study of the problem of musical and executive development of S. Prokofiev's cycle "Children's Music". The practical development of "Children's Music" is associated with the need to learn the composer's piano style, its specifics, and its innovation. The article defines the intonation and design features of the musical language. The author considers the plays in which the personality traits and creative tendencies of Prokofiev's art are most fully revealed.

The distinctive features of Prokofiev's handwriting are revealed: original harmony, unusual melodic turns, colorful modulation moves, acoustic stratification of texture, logic, dynamics and phrasing. The author analyzes the peculiarities of melodics - song, recitative, and "synthetic". The important questions of Prokofiev's polyphony in "Children's Music", which are poorly illuminated by researchers, are touched upon, as well as the question of the performance of the motional structures of "short breath".

Keywords: the album of piano pieces "Children's Music" byS. Prokofiev, the specifics of the new, modern language, the originality of the composer's musical thinking, the originality of his melody, harmony, rhythm, texture.

\author{
Кезевадзе Тамара Григорьевна \\ К.п.н., дочент, Московский педагогический \\ государственный университет \\ tomadeda@icloud.com
}

Аннотация: Статья посвящена исследованию проблемы музыкально-исполнительного освоения цикла С. Прокофьева «Детская музыка».

Практическое освоение «Детской музыки» связывается с необходимостью познания фортепианного стиля композитора, его специфики, его новаторства. В статье определяются интонационные и конструктивные особенности музыкального языка. Рассматриваются пьесы, в которых наиболее полно выявились черты индивидуальности и творческие тенденции искусства Прокофьева.

Раскрываются отличительные черты прокофьевского почерка: самобытная гармония, необычные мелодические обороты, красочность модуляционных ходов, акустическое расслоение фактуры, логика, динамика и фразировка. Анализируются особенности мелодики - песенной, речитативной, «синтетической».

Затрагиваются важные, малоосвещенные исследователями вопросы прокофьевской полифонии в «Детской музыке», а также вопрос исполнения мотивных строений «короткого дыхания».

Ключевые слова: альбом фортепианных пьес «Детская музыка» С. Прокофьева, специфика нового, современного языка, самобытность музыкального мышления композитора, своеобразие его мелодики, гармонии, ритмики, фактуры.

ний день. Существует понятие «прокофьевская эпоха».

позиторов (1891-1953 гг.), классик музыки XX века. В его произведениях с необычайной ясностью проявился переход от русской классической - к современной музыке. Фортепианные сочинения композитора, великого пианиста - одна из наиболее интересных и обширных областей его творчества. Они послужили основой для формирования стиля Прокофьева, открыв новую главу не только в русском, но и мировом фортепианном искусстве. По всему миру звучат фортепианные произведения Прокофьева.

Статистика неоднократно подтверждает, что Прокофьев стал «одним из репертуарных авторов XX века» [9, c. 456]

С. Прокофьев является зачинателем нового, современного музыкального языка, который широко используется в музыкальном искусстве с XX века по сегодняш-
С. Прокофьева привлекали поиски не просто нового языка, а языка сильнодействующего, впечатляющего. Прокофьева вдохновляла одна цель: «создавать музыку, обладающую способностью воздействовать на слушателя» - отмечает М. Тараканов [6, с.10]. «Прокофьеву удалось достичь того, что ожидал Ф. Гендель от своей музыки - а именно - сделать людей лучше.» [17, с.365] Такую мечту и цель ставили в своем творчестве лучшие, передовые композиторы своего народа, среди которых назовем Ф. Листа.

Стиль Прокофьева представлен органическим сплавом классического и современного. В значительной части своих произведений Прокофьев опирался на русский фольклор и традиции «кучкистов». В немалой степени Прокофьев воспринял и ряд черт современной классики 18 - начала 19 века: Моцарта, Гайдна, раннего 
Бетховена, отчасти - Д. Скарлатти, новаторски переосмысливая их. «Прокофьев впитал и новизну ладового мышления импрессионистов, свободу модуляционных планов, меткость изобразительных эффектов. Немало общего у Прокофьева со своеобразным «неоклассицизмом» позднего Дебюсси и Равеля», - отмечает И. Нестьев. $[10$, c.25]

Черты стиля композитора отчетливо проявились в фортепианном цикле «Детская музыка». Исследователи творчества Прокофьева справедливо оценивают сборник как «азбуку прокофьевского стиля». Пьесы цикла составляют «золотой репертуар пианиста» и представляют большую педагогическую ценность. Сборник принадлежит к числу лучших в мировой фортепианной литературы для детей.

Идею создания пьесы для детей подсказала Прокофьеву Вера Владимировна Алперс - друг и соученица Прокофьева по Петербургской консерватории, блестящая концертирующая пианистка и педагог. В одной из дружеских бесед Алперс посетовала Прокофьеву на недостаток педагогического репертуара и попросила композитора сочинить небольшие пьески для детей. Сам Прокофьев понимал, что «надобность в детской литературе ощущалась явно». [4, с.95] Так появился в 1935 году сборник «Двенадцать легких пьес» ор. 65, обозначенных Прокофьевым «Детская музыка».

«Детская музыка» стала важной вехой в творческом пути Прокофьева. Пьесы открывают мир восхитительного творчества Прокофьева для детей. Ведь большинство сочинений для детей были написаны с 1935 по 1939 годы», Д. Кабалевский в своем предисловии к «Детской музыке» писал: «Для маленьких любителей музыки сочиняли многие, почти все композиторы, но мало кто уделял этой области творчества столько внимания, столько серьезных размышлений и сердечного тепла, сколько уделял Прокофьев.» [4, с.130]

При создании «Детской музыки» Прокофьев опирался на лучшие страницы детской музыки - Р. Шумана, П.И. Чайковского. Композитору удалось в музыке цикла передать мироощущение самого ребенка.

В каждом из названных сборников включен определенный сюжет. В «Детском альбоме для юношества» Р. Шумана переданы сюжеты из жизни детей в течение целого года. У Чайковского - это день, прожитый ребенком в течение дня в поместье. В сборнике Прокофьева - это «приключения» ребенка в солнечный летний день от восхода солнца («Утро») до ночных сумерек («Ходит месяц над лугами»). То, что речь идет именно о летнем дне, видно не только из заголовков пьес. Существует оркестровая версия 7 из 12 номеров цикла, названная композитором «Летний день» (op.65 bis, 1941 г.)
По примеру детских пьес Шумана и Чайковского, все пьесы цикла имеют программные заголовки. У пьес четко выражены трехчастность с чертами сонатинности. Прокофьев пишет в «Автобиографии»: «Я сочинял легкие пьески для детей, в которых проснулась моя старая любовь к сонатинности, достигшая здесь, как мне казалось, полной детскости. К осени их наблюдалась полная дюжина». [4, с.96]

Сонатинность у Прокофьева - это тяготение композитора к старинному стилю с ясностью, жизнелюбием классиков (Гайдна, Моцарта), стремлением к прозрачности фактуры, лаконичности изложения. Композитор стремился передать в детской музыке чистоту, свежесть, непосредственность и солнечную радость, свойственную детскому восприятию мира. «Появляется пристальный в своей ясности взгляд на мир изумленными, широко раскрытыми, вопрошающе пытливыми глазами ребенка». [4, с.97] Каждая пьеса цикла поражает красочностью, живописностью, лаконичностью в сочетании с изложением, доступным для восприятия.

Мир разных жизненных явлений, который изучает пытливый детский ум, представлен в виде пьес-картинок, которые озарены живительным светом солнечных лучей летнего дня. Прокофьев - светлый и радостный художник, в котором «поет стихия света и тепла, в нем претворилась солнечная энергия и звучит неискоренимая тяга к жизни» - отмечает Б. Асафьев. [4, с.27] Знаменито изречение А. Рубинштейна: «Вы, мой дорогой Прокофьев, могли бы сказать «Солнце - это я»». [там же]

В каждой пьесе - разный характер действия. Тут впечатления ребенка от природы: «Утро», «Дождь и радуга», «Вечер», «Ходит месяц под лугами», плывущие облака В «Раскаянии» (средний эпизод) (П. Ройзман и В. Натонсон удачно ассоциируют средний эпизод «Раскаяния» $\mathrm{C}$ картиной природы [13]), прогулки и игры: «Прогулка», «Пятнашки», «Шествие кузнечиков», «Марш», танцы: «Тарантелла», «Вальс», рассказы «Сказочка» (Несмотря на определенную сюжетную линию, пьесы «Детской музыки» могут исполняться совершенно изолированно. Их уровень трудности - 3-7 классы.).

Мир детских образов и настроений связан с интонационно-ритмическим языком современности. В «Шествии кузнечиков» (эпизод «Роco meno mosso»), в «Тарантелле» (средний эпизод, кода) можно угадать сигналы пионерского горна, а в «Марше» еще и тонко претворяемые интонации солдатской песни (средний раздел).

Неповторимый почерк композитора - новатора ярко и отчетливо проявляется в поэтических картинках воплощения природы. Пейзажи у Прокофьева залиты солнцем. Это подлинное царство света. В этом мы видим проявление детского видения мира. Даже в вечерних 
пейзажах композитор утверждает мажорную тонику («Вечер»). В пьесе «Ходит месяц над лугами» используется классический прием усиления света - сочетания мажорных тональностей в соотношении большой терции. В пьесе «Дождь и радуга» почти целиком диатоника -C-dur-ная «тема удивления» перед происходящим (радуга-дуга), перекрывающая небосвод. На утверждении мажора, модификации Т трезвучия построено начало пьесы «Утро», напоминающее солнечные блики, игру светотеней. В этой пейзажной зарисовке ощущается пространство, воздух. Композитор использует приемы импрессионистов (в сочетании с классицистскими). Вместе с тем почерк здесь типично прокофьевский - параллельные движения, скачки, охват всей клавиатуры, игра через руку, четкий ритм, определенность разделов (Для усиления эффекта светотеней, для эффекта ночных теней нами рекомендуется педальный наплыв на звучание аккордов средних голосов в начале пьесы.).

Оригинальная пьеса «Дождь и радуга» - «самая картинная из всех прокофьевских миниатюр, посвященных образам природы», как справедливо отмечает А.Д. Алексеев и называет ее «маленьким шедевром звукописи, где достигнута полная слиянность слышимого и видимого образа». [2, с.138] В ней композитор использовал импрессионистическую звукопись, например смелые аккордовые «кляксы» или монотонное повторение одной ноты, изображающей стук дождя (В этой ритмоформе и последующей за ней ум3 и разрешением в звук ре автору статьи слышатся интонации русской народной песни-заклинания «Гори, гори ясно, чтобы не погасло». Это сходство усиливается, если употребить рекомендуемую А.Д. Алексеевым в «Методике» [1] педаль на весь такт).

Пьесам - картинкам пейзажных зарисовок контрастом выступают номера цикла, в которых преобладает стихия движения, жеста, пластики. Сам Прокофьев обладал природным динамизмом натуры: «Я не люблю пребывать в состоянии, я люблю быть в движении» - известное высказывание Прокофьева, приводимое многими музыковедами. Больше половины пьес цикла - двигательного характера. В них запечатлены различные виды движения: солнце постепенно всходит, облака плывут, дождь стучит, дети танцуют и играют в пятнашки, маршируют, идут на прогулку, месяц ходит, песня льется.

«Подпрыгивающая походка» свойственна детям, «осаливание» присутствует в игре пятнашки, движение колыбели ассоциируется с убаюкиванием ребенка. В названных пьесах проявились такие черты стиля Прокофьева, как: его жизнелюбие, юмор, предельная яркость, необычная гармония, частые модуляционные изменения. Этим пьесам свойственны остинатность и токкатность - характерные черты композиторского письма XX века.
Большую роль в пьесах двигательного характера играют акценты, особенно в «Тарантелле», «Пятнашках», «Марше». Они являются, перефразируя Б. Асафьева, оформляющим фактором, вносящим заостренность, капризность. Это касается и диссонансов. По словам Прокофьева «Он должен занять надлежащее ему место в музыке как один из принципиально важных элементов, возникающих при сочетании мелодических линий» (из беседы с американским критиком Олин Даунсом). [10, c.23]

Изображение действия не противоречит песенности. Так, «Шествие кузнечиков» - озорная песня, в которой слышатся оттенки человеческой интонации, хотя в пьесе музыковеды усматривают и галоп, и черты маршевости, а в средней части - фанфарные звучности. В знаменитом «Марше» наблюдается разнообразие движений, множество метро-ритмических нюансов. В рамках моторного жанра вплетены интонации удалой песни. Нарушение энергии происходит и в «тихой кульминации» со сменой динамических оттенков. При исполнении этой пьесы возможны агогические оттяжки $(4,6,12,14$, такты) как они могут быть при движении мелодии вверх с «сопротивлением».

Нарушение инерции характерно для Прокофьева. Оно проявляется во всех моторных пьесах. Этим нарушением преодолевается механистичность - и в этом вся свежесть прокофьевской музыки. В качестве примеров остановимся на «Вальсе» и «Тарантелле». Прерывистоприхотливая тема «Вальса» интересна непредсказуемыми поворотами мелодии, неожиданными гармоническими переходами. В стремительной «Тарантелле» живой, бойкий ритм нарушается упругими акцентами, полутоновыми тональными сопоставлениями, сдвигами однотональных сопоставлений. Исследователи отмечают поэтику контрастов как внутри самих пьес, так и в сюитном расположении пьес и усматривают в этом логику прокофьевского музыкально-сценического мышления, театральность, законы контрастного построения сцен. Примечательно: в недрах одной и той же пьесы - два начала: одно связано с игровыми, или красочно-колористическими образами, другое - с лирическими («Утро», «Тарантелла», «Дождь и радуга»). «Композитор как бы завлекает маленького слушателя подвижным характером, яркой игрой красок в начале пьесы, а потом заставляет его внимать и лирическому распеву» $[8$, с.26] - пишет исследователь прокофьевской музыки М. Корсунская. И далее: «Так музыка Прокофьева становится великолепным и умным «воспитателем нежности», развивая в детях способность к постижению разных сторон жизни» [там же]. Проницательное высказывание принадлежит А. Есиповой, учившей Прокофьева музыкальному искусству: в ответ на вопрос, какое качество она более всего ценит в музыке своего ученика, Анна Николаевна ответила «Нежность». Это точно найденное слово могло 
бы послужить девизом для всех, кто обращается к прокофьевскому циклу.» [7, с.10] Хочется добавить к этому важные слова замечательной пианистки В. Разумовской: «Главное для исполнителя - передать не только красоту музыки Прокофьева, но и бесконечную доброту.» [7, с.7]

Бесподобная лирика - самое дорогое качество музыки Прокофьева. Многие писали о Прокофьеве как о творце прекрасных мелодий. Приведем некоторые примеры: «Горным цветком, поражающим запахом и прелестью» назвал музыку Прокофьева Э. Гилельс; «Целомудренно чистая, хрустальная лирика композитора обладает неповторимым колоритом» - отмечает М. Тараканов. [7, с.710]

В лирических пьесах, в их мелодике отчетливо проявляется связь музыки Прокофьева с народным искусством. «Народная песня - подлинная основа музыкальной речи Прокофьева. Он преломляет стилевые особенности русской песни свободно и индивидуально». [2, с.136] Среди лирических пьес сборника назовем «Ходит месяц над лугами». Мелодия этой миниатюры кажется подлинно народной, хотя в действительности сочинена композитором, о чем он счел нужным упомянуть в «Автобиографии». По чистоте мелодического рисунка и спокойной плавной ритмике она близка русским хороводным песням. Своей широкой русской песенностью и колоритом привлекает «Вечер». О великом лирическом даре Прокофьева говорит и тихая, нежная и очень русская по характеру и мелодии «Сказочка». В ней мелодия верхнего голоса - тема «рассказа» - по мнению музыковедов напоминает русский жалеечный наигрыш, а остинатный контрапункт интонационно ассоциируется с русской народной песней-колыбельной «Баю, баюшки баю, не ложися на краю». Подтекстовка этого мотива словами указывает на несомненную идентичность с этой песней (Эта особенность очень верно отмечена в статье М. Корсунской).

Помимо песенных мелодий с русским колоритом в «Детской музыке» есть пьесы иного типа, которые отличаются выразительной декламационностью. Она представлена в пьесе «Раскаяние» («Стыдно стало»). Прокофьев здесь использует тип «поюще-говорящих» (по определению Л. Мазеля) «синтетических» мелодий, в которых элемент речитативной выразительности не уступает место выразительности кантиленной.

Впечатление выразительной льющейся речи производит мелодика пьесы «Утро»: музыка эпизода средней части, который можно определить как «гимн солнцу» (Алексеев), обладает декламационной выразительностью. Оттенки речевой выразительности проявляются и в «Шествии кузнечиков».

Л. Баренбойм в статье «О музыкально-педагогиче- ском репертуаре» писал: «Как нам не хватает детских инструментальных пьес, опирающихся на речевые интонации, на вокально-речевую декламационность! Как облегчила бы такая музыка путь ребенка к современным композиторам разных поколений.» [15, с.9] Прокофьев проложил путь к широкому распространению вокальноречевых мелодий в музыке композиторов XX века.

Одно из важных средств выразительности в «Детской музыке» Прокофьева - полифония. Для полифонического письма Прокофьева характерна тонко дифференцированная ткань, прозрачное голосоведение, мелодическая самостоятельность подголосков, контрапункт ostinato, имитация, соединение темы и противосложения, разнотемное двухголосие. Примером прокофьевской полифонии, где в полифонической ткани сплетаются голоса, каждый из которых обладает присущим ему своеобразием, может служить двухголосная полифония «Сказочки». Здесь контрапункт не противостоит характеру темы, а, наоборот, углубляет ее. Имитация встречается в пьесахпейзажах «Вечер», «Ходит месяц над лугами». Полифония здесь служит колористическим средством. Типичный образец имитационной полифонии - средний раздел пьесы «Прогулка». В этой пьесе песенность сочетается с интенсивным динамическим ростом - и в этом полифония играет главную роль. Начало полифонического эпизода (стретто) - однозвучный затакт-предъем к сильной доле (20-21 такты). Ответ более динамичен: однозвучный затакт не совпадает по высоте с последующей более высокой сильной долей. Мелодия (фа-ля) устремляется снизу вверх, что усиливает ямбическую волну. Третье проведение еще более динамизировано: два слабых звука предшествуют ударному си1-до1-ре2-28-29 такты). Процесс динамизации продолжается с усилением звучания. «Исполнитель должен передать масштабность динамического нарастания. Важно показать широту дыхания темы в разных голосах, в каждом из которых длинные лиги помогают выявить протяженность фраз». [8, с.31]

Взаимодействие самостоятельных мелодий (в основном двух) различаются по своей протяженности, но в большей части для них характерно слияние. Этот вид прокофьевской полифонии наиболее часто встречается в «Детской музыке».

В некоторых пьесах альбома «Детская музыка» педагог и исполнитель сталкиваются с такой особенностью, как кратность мотивов, когда фраза делится на мотив. Это выражается в прерывистости дыхания мелодики, отмеченной короткими лигами или короткими паузами. В этом есть своя динамика фразы, особенность ее развития. Фраза имеет свою кульминацию, к которой устремляется мелодическая волна, она имеет естественное завершение. Надо избегать исполнения мелодии по мотивам. Мотив - это единица измерения, составляющая фразу. Есть фраза, протяженность мелодической линии, 
составленной из мотивов. Например, «Прогулка». Здесь необходимо суммирование $2+2+4$. Имеет место тип экстенсивного развития, требующий спадающей динамики.

В пьесе «Вальс» важно объединение звучности однотактов (средняя часть) в восьмитактное построение (3 такта D + 1 так е + 3 такта fis +1 такт $\mathrm{H}$ ).

Во всех случаях музыканту-исполнителю необходимо избегать квадратной разрозненности мотивов, стремлений акцентировать квадратность структуры. Главное понять живое развитие мысли, динамику фразы, осмыслить свойства прокофьевской мелодики - ее широту, протяженность.

Характерность мелодики Прокофьева неразрывно связана с ладогармонической стороной его стиля. В цикле «Детская музыка» Прокофьев остался приверженцем тональной музыки. В анализе гармонического языка теоретики применяют термин «расширенная тональность», «двенадцатиступенная тональность». В музыкальной литературе признано, что гармония Прокофьева - явный образец современности, в то же время во многом сохранивший преемственность.

Почти во всех пьесах цикла Прокофьев использует тональность с минимумом ключевых знаков, но обогащает их введением альтерированных аккордов (доминанты и двойной доминанты), обострением аккордовых тяготений, ярких акцентов, смещенных на вторую долю. Для ладового мышления характерны политональность, ладовое перечье. Гармонию Прокофьева отличают аккорды с внедряющимися или замененными ступенями, септаккорды с квартами и тритонами вместо терции.

В «Детской музыке»- немало новейших приемов, обозначенных как «прокофьевские»:

Самый новаторский - использование однотерцовой системы, рождающей расширенную тональность. При анализе «Ходит месяц над лугами» в настоящей статье мы обращали на это внимание. Упомянем пьесы «Вечер», «Раскаяние», «Тарантелла».

Вместо поступенного звукоряда применяются выразительные нисходящие ходы на септиму. Этот новаторский прием носит название «разомкнутая поступенность» (пьесы «Прогулка», «Вальс»).

Использование средств мажора-минорной (одноименных тоник). Например, смена d-moll-D dur в «Taрантелле» используется для передачи изменения настроения. В «Пятнашках»- смена действия. «Дождь и радуга» - смена природных явлений.

Использование неоклассической гармонизации, в том числе - «прокофьевской доминанты» с повышенной септимой («Утро», «Марш», «Вальс», «Шествие кузнечиков», «Дождь и радуга», «Тарантелла», «Прогулка»).

Использование нетрадиционных способов перехода в другие тональности, их сопоставление и скорость («Пятнашки», «Шествие кузнечиков», «Тарантелла», «Вечер», «Ходит месяц над лугами» и др.)

Интересны и другие гармонические приемы:

Использование фонической окраски созвучий как мощного выразительного средства. Благодаря выявлению красочности регистров создаются звучания разных тембров (светлый, прозрачно-густой, темный).

Интересны приемы «тихой кульминации» («Утро», «Раскаяние», «Марш»), своеобразна и современна стилизация русской музыки. Вместо T-D-D-T, как у классики (вопросо-ответная форма), у Прокофьева представлены плагальные обороты и их модификации (пьеса «Ходит месяц над лугами»)

Свежую краску вносят полифункциональные аккорды в кадансовых оборотах (к примеру, в «Пятнашках», «Марше»), расширение и модификация традиционного До мажора («Дождь и радуга», «Утро»). Примечательно органичное сочетание диатоники и хроматики, многообразие вариантов D гармонии, в том числе - доминанты с расщепленной квинтой, превращение одной ноты в многослойный кластер («Дождь и радуга», «Марш»).

Справедливы слова Ю. Холопова: «Прокофьев убедительнейшим образом доказал, что новая гармония позволяет с большей остротой и проникновенностью, с большей эмоциональной силой и непосредственностью может выразить новое содержание искусства нашего времени, чем это может сделать старая гармония.» [7, c.47]

Прокофьев не раз в своем творчестве возвращался к пьесам цикла «Детская музыка». Так, в балете «Сказ о каменном цветке» композитор использовал музыку пьесы «Вечер» в качестве темы любви Екатерины и Данилы. Она стала важнейшим лейтмотивом балета. В этом же балете в точности воспроизведен «Вальс» в сцене (№19), изображающей владение хозяйки Медной горы. Образность пьесы «Шествие кузнечиков» нашла сходное воплощение в балете «Золушка» (в сцене кузнечика и стрекозы). Нити от «Детской музыки» тянутся и к другим сочинениям композитора.

В своей «Автобиографии» Прокофьев специально остановился на тех главных линиях, по которым двигалось его творчество: 1) классичность (опора на традиционные формы и жанры, преобладание диатоники над 
хроматикой, прозрачная, экономичная фактура); 2) новаторство («угловатые» мелодические линии, диссонантные гармонии, элементы политональности); 3) лирика; 4) токкатность (быстрое, отчетливо ритмизированное движение); 5) скерцозность, приобретающая разнообразные оттенки - от мягкой иронии до гротеска.

В нашей статье мы опирались на высказывание С. Прокофьева о главных линиях его творчества и в соответствии с ними шли по пути к освоению ярко-национального, самобытного фортепианного цикла «Детская музыка», показав один из возможных музыкально-исполнительских, а также педагогических подходов к его практическому освоению.

Самобытность музыкального мышления С. Прокофьева, своеобразие и красота мелодики, ритмики открыли новые пути в музыке и оказали мощное воздействие на многих советских и зарубежных композиторов. «Детская музыка» Прокофьева послужила стимулом для создания композиторами большого количества произведений на детскую тематику. Пьесы сборника далеко выходят за рамки педагогического репертуара. «Благодаря своей высокой художественной ценности они могут доставить наслаждение и взрослым людям - каждому, кому дорог мир чистой поэзии детства» (А.Д. Алексеев).

\section{ЛИТЕРАТУРА}

1. Алексеев А.Д. Методика обучения игре на фортепиано. М.: Музыка, 1971, 278 стр.

2. Алексеев А.Д. Советская фортепианная музыка. 1917-1945. М.: Музыка, 1974, 248 стр.

3. Блок В. Детская музыка С. Прокофьева // сб. Вопросы фортепианной педагогики. - Вып. 3. М.: Музыка, 1971, 333 стр., с. 130-148

4. Дельсон В.Ю. Фортепианное творчество и пианизм Прокофьева. М.: Советский композитор, 1973, 333 стр.

5. Кабалевский Д. О Сергее Прокофьеве и его музыке для детей. Предисловие к изданию «Детская музыка» 12 легких пьес для ф-но. М., 1980.

6. Коврикова Е.В., Э.Б. Литвинова 0 музыке С. Прокофьева. Вопросы изучения и исполнения. Музыкальные рекомендации для студентов музыкальных факультетов педагогических Вузов. Т.Г.П.У. Казань. 2009. http://kpfu:n

7. Корнилова Л.А. С.С. Прокофьев «Детская музыка» (методическое пособие для преподавателей ДМШ). Систематизация педагогического опыта. Преподаватель отделения специального фортепиано ДШИ. НГ/МБОУ/ДОД dshimgansk.ru

8. Корсунская М.Л. Детская музыка С. Прокофьева в художественном воспитании школьника. // Статья. Сборник трудов Инструментальное обучение на музыкально-педагогическом факультете. М.: МГПИ, 1973, с. 25-37

9. Музыкальная энциклопедия, т. 4. М.: Советская энциклопедия, 1978, с. 456-457

10. Нестьев И. Классик XX века. // Статья: Сборник Сергей Прокофьев. Статьи и материалы. М.: Музыка, 1965, с.11-54

11. Прокофьев С. Автобиография. М.: Советский композитор, 1982, 600 стр.

12. Прокофьев С. Статьи и материалы. 2ое изд., М.: Музыка, 1965, 400 стр.

13. Ройзман Л., Натансон. Методические замечания к «Альбому детских пьес». М.: Советский композитор, 1958.

14. Тюлин Ю.Н. Современная гармония и её историческое происхождение // Вопросы современной музыки. Л., 1963; статья в сб.: Теоретические проблемы музыки ХХ века, вып. 1, М., 1967., 512 стр.

15. Усманова Е.В. Фортепианные произведения С.С. Прокофьева в учебном репертуаре студентов музыкально-педагогических факультетов. Учебно-методическое пособие. М.: МГПУ, 2008, 48 стр.

16. Шимырева Л.Я. Сергей Прокофьев. Соч.65 «Детская музыка 12 легких пьес для фортепиано». Опыт работы над фортепианным циклом на примере «Детской музыки» Прокофьева. Преподаватель фортепианного отделения МБУДШИ «Гармония» Углегорского р-на Сахалинской области. http://dshi-ugl.shl.muzkult.ru

17. Эйслер Г. Огромное завоевание. // Зарубежные музыканты о Прокофьеве. Статья в кн. Сергей Прокофьев. Статьи и материалы. М.: Музыка, 1965, с. 365 (c) Кезевадзе Тамара Григорьевна (tomadeda@icloud.com). 